(see Table). On the basis of the present data it is not known whether the raised F.D.P. titres are due to fibrinogen or fibrin breakdown products, since the staphylococcal clumping assay is sensitive to both. Unfortunately it proved impracticable to obtain other supporting data which might have allowed us to distinguish between the two types of F.D.P. Very probably, however, raised F.D.P. titres in toxaemia and eclampsia are due to secondary fibrinolysis and that mainly fibrin degradation products are being measured. Primary fibrinolysis is a relatively rare condition; moreover, the F.D.P. titres found in eclampsia were very similar to those found with the staphylococcal clumping assay in typical acute disseminated intravascular coagulation (Thomas, Niewiarowski, Meyers, Bloch, and Colman, 1970).

Our findings support the hypothesis that disseminated intravascular coagulation is occurring in eclampsia and is responsible for many of the clinical manifestations by causing widespread occlusion of the small vessels in the kidneys, brain, and other organs. A similar but milder process, where fibrin deposition is limited to the renal microcirculation, may occur in toxaemia (McKay et al., 1953; McKay and Corey, 1964). The possibility that much of the implied increase in fibrin formation takes place in the uterine and placental vessels (Woodfield et al., 1968) cannot be excluded. It has been postulated that disseminated intravascular coagulation could be triggered by the release of thromboplastin from the placenta (McKay and Corey, 1964). A similar mechanism has also been proposed to account for the depletion of clotting factors and the rise in F.D.P. after abruptio placentae and fetal death-in-utero (Bonnar et al., 1969a). The differences between the various clinical syndromes associated with disseminated intravascular coagulation in pregnancy may in part be attributed to the quantitative differences in the rates and sites of fibrin formation and subsequent lysis.
We thank Mr. J. Nshaho, Mrs. Elizabeth Hutchinson, and Mrs. Lynn Smith for their invaluable assistance. We also thank Professor R. R. Trussel and Professor A. G. Shaper for their encouragement and advice. This work was supported by a grant from the United States Public Health Service (HE-09203) and also by a grant from Roche Products Ltd.

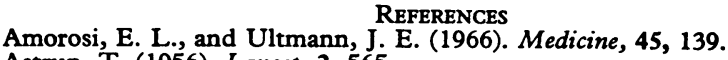

Astrup, T. (1956). Lancet, 2, 565.

Biezenski, J. J., and Moore, H. C. (1958). Fournal of Clinical Pathology, 11, 306.

Bonnar, J., Davidson, J. F., Pidgeon, C. F., McNicol, G. P., and Douglas, A. S. (1969a). British Medical fournal, 3, 137.

Bonnar, J., McNicol, G. P., and Douglas, A. S. (1969b). British Medical Fournal, 3, 387.

Brain, M. C., Dacie, J. V., and Hourihane, D. O'B. (1962). British fournal of Haematology, 8, 358 .

Brain, M. C., Kuah, K.-B., and Dixon, H. G. (1967). Fournal of Obstetrics and Gynaecology of the British Commonwealth, 74, 702.

Govan, A. D. T. (1961). Pathologia et Microbiologia, 24, 561.

Hawiger, J., Niewiarowski, S., Gurewich, V., and Thomas, D. P. (1970). fournal of Laboratory and Clinical Medicine, 75, 93.

Fournal of Laboratory and Clinical Medicine, 75, 93.
McKay, D. G. (1964). Circulation, 29, Suppl. No. 2, p. 66.

McKay, D. G., and Corey, A. E. (1964). Obstetrics and Gynecology, 23, 508. McKay, D. G., Merrill, S. J., Weiner, A. E., Hertig, A. T., and Read, D. E. (1953). American fournal of Obstetrics and Gynecology, 66, 507

McKay, D. G., and Shapiro, S. S. (1958). Fournal of Experimental Medicine, $107,353$.

Merskey, C., Kleiner, G. J., and Johnson, A. J. (1966). Blood, $28,1$.

Morris, R. H., Vassalli, P., Beller, F. K., and McCluskey, R. T. (1964). Obstetrics and Gynecology, 24, 32

Nilsson, I. M., and Kullander, S. (1967). Acta Obstetrica et Gynecologica Scandinavica, 46, 273.

Pechet, L., and Alexander, B. (1961). New England fournal of Medicine, 265, 1093 .

Talbert, L. M., and Langdell, R. D. (1964). American fournal of Obstetrics and Gynecology, 90, 44

Taub, R. N., Rodríguez-Erdmann, F., and Dameshek, W. (1964). Blood, 24, 775 .

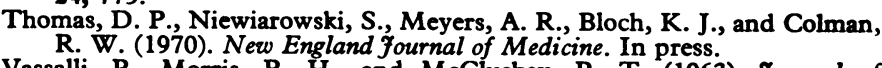

Vassalli, P., Morris, R. H., and McCluskey, R. T. (1963). Fournal of Experimental Medicine, 118, 467.

Wardle, E. N., and Menon, I. S. (1969). British Medical Fournal, 2, 625

Woodfield, D. G., Cole, S. K., Allan, A. G. E., and Cash, J. D. (1968) British Medical fournal, 4, 665.

\title{
Cortisol and Growth Hormone Secretion in Relation to Linear Growth: Patients with Still's Disease on Different Therapeutic Regimens
}

\author{
R. A. STURGE,* M.B., B.S. ; C. BEARDWELL, † M.B., B.SC., M.R.C.P. ; M. HARTOG, $\ddagger$ D.M., M.R.C.P.

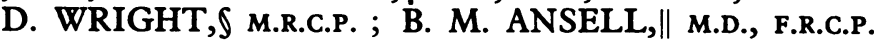

British Medical fournal, 1970, 3, 547-551

\begin{abstract}
Cummary: Linear growth was studied in 20 children suffering from Still's disease on various treatment regimens, and their ability to secrete growth hormone and cortisol was investigated. Growth recovered on reducing daily corticosteroid therapy or on changing to an alternative regimen. Retardation of growth was not due to an absolute inability to secrete growth hormone. Basal plasma cortisol levels and the plasma cortisol response to hypoglycaemia were reduced in patients on daily steroid therapy, but patients on alternate-day prednisone did not differ significantly in this respect from those on non-steroid regimens. Those on alternate-day corticotrophin showed preservation of the circadian rhythm but a subnormal response to hypoglycaemia.
\end{abstract}

\section{Introduction}

Interference with statural growth in children by corticosteroids is well recognized both in those with Cushing's

\footnotetext{
- Senior House Officer, M.R.C. Rheumatism Research Unit, Canadian Red Cross Memorial Hospital, Taplow, Bucks † Medical Registrar, Hammersmith Hospital, London W.12. ₹ Senior Medical Registrar, Hammersmith Hospital, London W.12. f Lecturer in Medicine, Hammersmith Hospital, London W.12. I| Consultant Physician, Canadian Red Cross Hospital, Taplow, Bucks.
}

syndrome (Talbot and Sobel, 1947) and in patients on longterm corticosteroid therapy (Blodgett et al., 1956). Suppression of the hypothalamic-pituitary-adrenal axis also occurs, and to overcome these problems intermittent corticosteroid or corticotrophin regimens have been advocated (Harter et al., 1963; Soyka, 1967; Friedman and Strang, 1966). At the M.R.C. Rheumatism Research Unit maintenance corticosteroid therapy in Still's disease has shown pronounced suppression of growth. For this reason patients have been changed to a regimen of prednisone or corticotrophin on alternate days, while in all cases dosage has been reduced to the lowest possible maintenance level. The present study was undertaken to investigate cortisol and growth hormone release in children with Still's disease on various regimens of steroid treatment and to compare the results with those in similar children who had never received corticosteroids. We have also attempted to correlate the results in the different treatment groups with linear growth.

\section{Method}

Twenty patients suffering from Still's disease and aged from 7.3 to 15.7 years were studied and divided into four groups (Table I). Group 1 had never received corticosteroid 
TABLE I.-Clinical Details

\begin{tabular}{|c|c|c|c|c|c|c|c|}
\hline 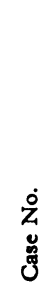 & 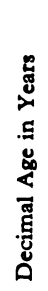 & ॐ & 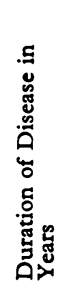 & 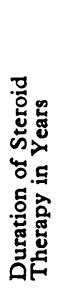 & 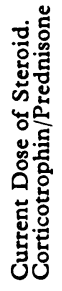 & 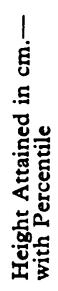 & 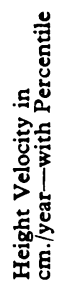 \\
\hline
\end{tabular}

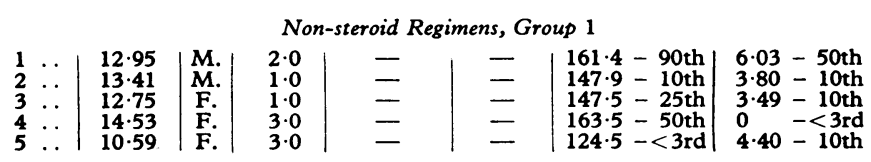

Daily Corticosteroid, Group 2

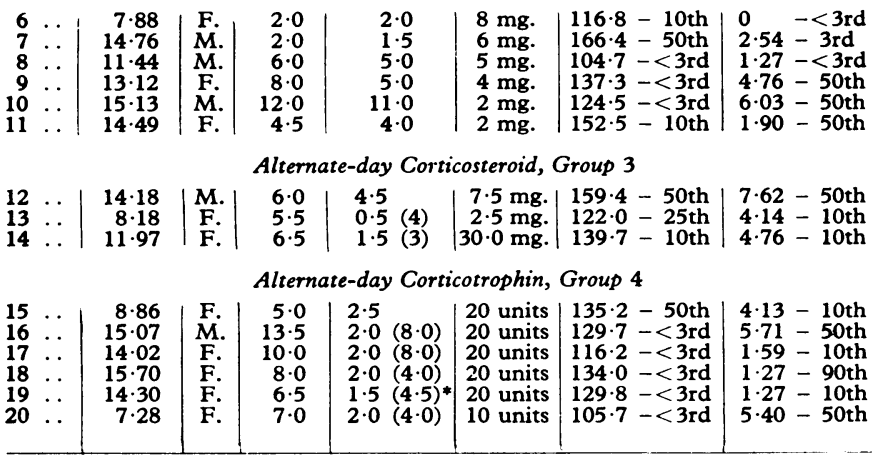

Figures in parentheses refer to previous daily corticosteroid therapy.

Daily corticosteroid plus intermittent corticotrophin for $4 \frac{1}{2}$ years.

therapy, while group 2 were taking prednisone in divided doses twice daily, the dose having been reduced to the lowest level compatible with clinical control of the disease. Groups 3 and 4 were being treated with prednisone or corticotrophin taken as a single morning dose on alternate days, seven of the nine patients having formerly received long-term daily prednisone. During the investigation doses of prednisone or corticotrophin were given at 9 a.m. and doses of prednisone, in those on daily therapy, at 9 p.m.

Height was measured regularly and plotted on standard percentile charts (Tanner et al., 1966) in relation to chronological age rather than bone age, which could not be accurately estimated, owing to the effects of disease on carpal epiphyses. The increments for calculating height velocity were taken over a whole year and tests for serum growth hormone and plasma cortisol were made at the midpoint of the year, when the height attained was also recorded.

All the children were long-term inpatients used to venepuncture, but to exclude so far as possible the effects of stress and exercise basal values for serum growth hormone and plasma cortisol were determined on blood taken on three consecutive days between 7 and 7.15 a.m. after overnight fast and before rising. With patients on daily prednisone this was 10 hours after the last dose, while with those on alternate-day therapy blood samples were taken 22 and 46 hours after the previous dose. An insulin hypoglycaemia test was made on completion of the basal studies, 10 hours after the last dose of prednisone in those on daily therapy and 46 hours after the last dose in those on alternate-day therapy.

The insulin hypoglycaemia test was performed on the fasting patient immediately after inserting an indwelling needle into a forearm vein. Hypoglycaemia was induced by injection of soluble insulin 0.1 unit per $\mathrm{kg}$. body weight through the needle, blood for estimation of blood sugar, growth hormone, and cortisol being withdrawn at $0,30,60$, and 120 minutes, with an additional blood sugar sample at 20 minutes. All patients except Case 5 showed evidence of a mild hypoglycaemic reaction, feeling hot, drowsy, dizzy, or hungry and with flushing, sweating, and restlessness. Symptoms were transient and none was distressed by the procedure. Blood sugar determinations were carried out with a standard ferroferricyanide method on an AutoAnalyzer (Technicon). The blood sugar in all except two (Cases 2 and 5) fell to $40 \mathrm{mg} . / 100 \mathrm{ml}$. or below, and this with clinical evidence of a hypoglycaemic reaction was considered a satisfactory response to insulin.

Serum growth hormone was determined by the radioimmunological method of Hartog et al. (1964) the M.R.C. preparation A of human growth hormone being used as standard. A rise in serum growth hormone of $5 \mathrm{ng} . / \mathrm{ml}$. or more above the basal level was regarded as the lower limit of a normal response to insulin-induced hypoglycaemia (Kaplan, 1969). Plasma cortisol measurements were made by a modification of the competitive protein-binding assay procedure of Murphy et al. (1967). The procedure was as described by Beardwell et al. (1968) for urine, except that 0.5 to $1 \mathrm{ml}$. of plasma was extracted with $10 \mathrm{ml}$. of dichloromethane and $2 \mathrm{ml}$. of the extract dried down in the assay tube before adding $1 \mathrm{ml}$. of $2 \%$ ethanol in $0.9 \%$ saline. The normal range of basal plasma cortisol at 7 a.m. was taken as $5-21 \mu \mathrm{g} . / 100 \mathrm{ml}$. and the response to insulin hypoglycaemia was considered normal if the maximum plasma cortisol concentration exceeded $20 \mu \mathrm{g} . / 100 \mathrm{ml}$. (Laron et al., 1969).

\section{Results}

\section{Growth}

Details of height attained and height velocity at the time of growth hormone and cortisol investigations are shown in Table I. Some growth retardation occurred in the patients in group 1 but except for one patient who had not grown at all in the year there was a reasonably close correlation between height attained and current height velocity. These patients

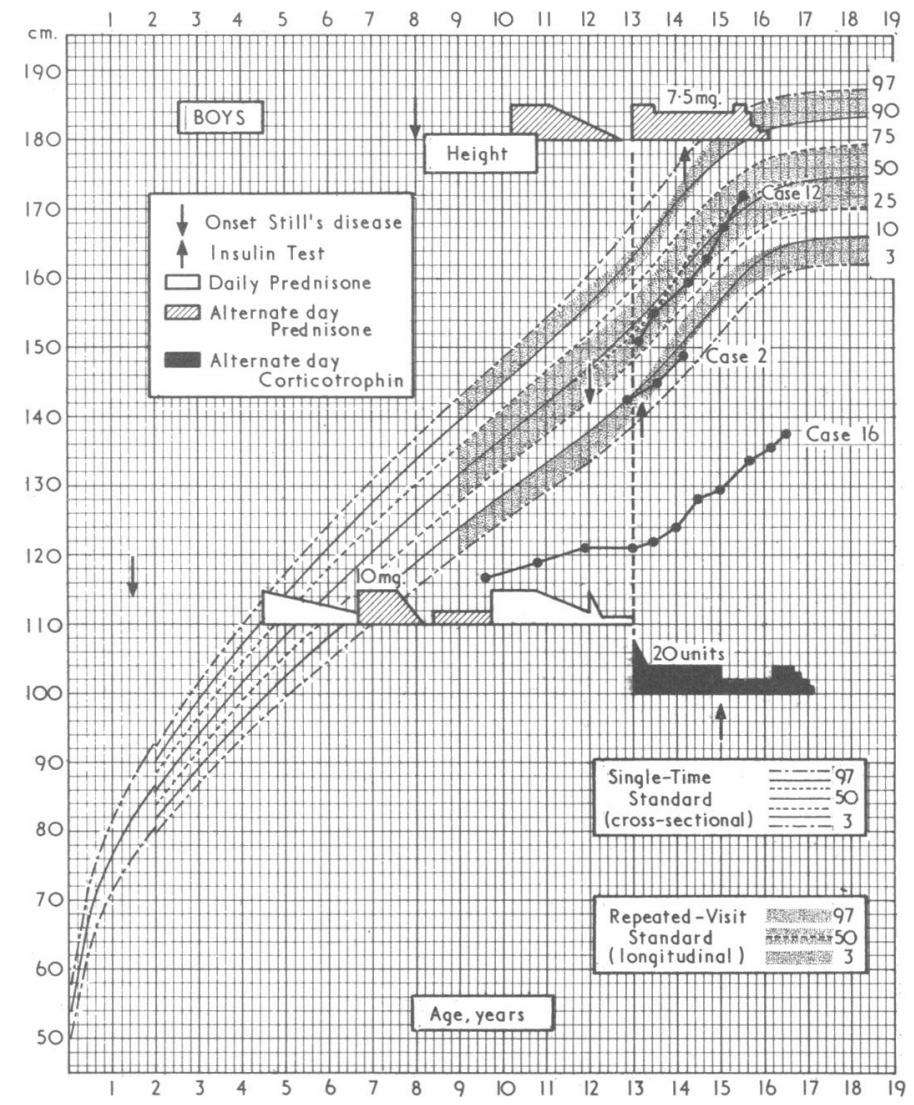

Fig. 1-Case 2, little or no growth retardation in patient with short history of Still's disease treated without corticosteroids. Case 12, two years after onset of disease started on alternate-day prednisone; normal growth along 50 th percentile. Case 16, three years after onset of disease started on daily prednisone; after eight years considerable growth suppression, changed to alternate-day corticotrophin with growth recovery. 
had suffered from Still's disease for a shorter time than most of those in the other groups. In group 2 those who had received prolonged daily corticosteroid therapy were below the third percentile for height attained, while those currently on the higher dose regimens were on or below the third percentile for height velocity. Conversely shorter periods of treatment and lower doses of prednisone were associated with little or no retardation in height attained and height velocity respectively. In group 3 all three patients showed normal growth, the one who had received alternate-day prednisone from the outset being on the 50th percentile for both height attained and height velocity. In group 4 the patient who had never received corticosteroids was on the 50th percentile for height attained though current height velocity was slow. In contrast the other five who had previously been treated with prolonged daily prednisone were all below the third percentile in height yet their current height velocities showed some recovery of growth.

Growth data for five patients are shown in Figs. 1 and 2. One who had never received corticosteroid therapy and the one who had received only alternate-day prednisone have normal growth while the other three show growth retardation associated with prolonged daily corticosteroid treatment, with recovery of growth in two on discontinuing the drug or changing to an alternate-day corticotrophin regimen.

\section{Basal Studies}

Serum Growth Hormone.-Basal growth hormone levels were similar in the four groups (Table II). All except three patients had mean basal levels below $5 \mathrm{ng} . / \mathrm{ml}$., the average being $3.2 \mathrm{ng} . / \mathrm{ml}$. The three with higher mean basal levels each had a single level over $10 \mathrm{ng} . / \mathrm{ml}$. In each of these patients this single high value was felt to be either not a truly

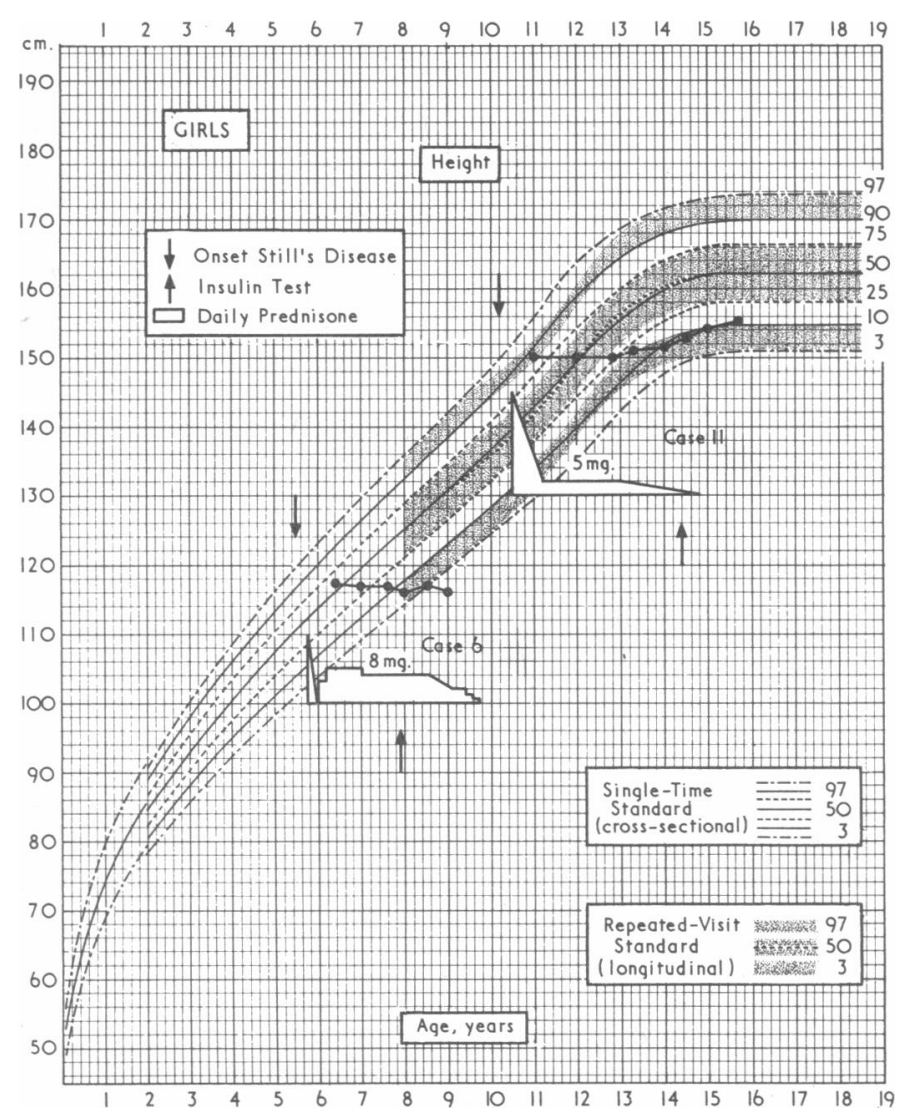

FIG. 2.-Case 11, continuous daily prednisone since onset of disease; growth failure with partial recovery when dose reduced below $5 \mathrm{mg}$. daily and finally discontinued. Case 6 , continuous daily prednisone since onset of disease;
pronounced osteoporosis with vertebral collapse; height loss of $1 \mathrm{~cm}$. over $2 \frac{3}{4}$ years. basal value or to be associated with a particular stress; two had been woken up and dressed before venepuncture, while difficulty was encountered in obtaining blood from the third. No difference was observed in the basal levels 22 and 46 hours after therapy in those receiving alternate-day corticotrophin or prednisone, and they did not differ from those on daily steroid therapy or no therapy at all.

Plasma Cortisols.-Mean basal plasma cortisol levels were within the normal range for all patients in group 1 but subnormal in five of the six in group 2 (Table II). The three in group 3 had normal mean basal plasma cortisol levels, as did five of the six in group 4. Those on alternate-day prednisone had lower plasma cortisol levels at 22 hours after the last dose of prednisone (mean $13.5 \mu \mathrm{g} . / 100 \mathrm{ml}$.) than at 46 hours (mean $19.7 \mu \mathrm{g} . / 100 \mathrm{ml}$.). Similarly, patients on alternate-day corticotrophin had lower levels at 22 hours (mean $8.9 \mu \mathrm{g} . / 100 \mathrm{ml}$.) than at 46 hours (mean $11.9 \mu \mathrm{g} . / 100 \mathrm{ml}$.).

\section{Insulin Hypoglycaemia Test}

Serum Growth Hormone.-Fasting levels of serum growth hormone on the day of the insulin tolerance test were slightly higher in over half the patients than their mean basal levels (Table II). Though an adequate hypoglycaemic stimulus was not achieved in two patients, all except one showed a maximum rise in growth hormone at 30 or 60 minutes that was within the normal range (Fig. 3). In two a subnormal response was obtained in spite of adequate hypoglycaemia, but a repeat test, in one case with a slightly higher dose of insulin ( $0.15 \mathrm{unit} / \mathrm{kg}$. body weight), resulted in a satisfactory response in both. The one patient who did not respond to hypoglycaemia had an already high basal growth hormone level, as did three others whose responses were in the lower range of normal.

Plasma Cortisols.-At the start of the insulin hypoglycaemia test four of the five in group 1 had fasting plasma cortisol levels higher than their mean basal levels (Table II) whereas in group 2 no difference was noted. The patients in group 3 also showed an increase above their mean basal levels, as did three of the six in group 4. After hypoglycaemic stimulation all patients in group 1 developed a maximum plasma cortisol level over $20 \mu \mathrm{g} . / 100 \mathrm{ml}$., in spite of inadequate hypoglycaemia in two; but no patient in group 2 showed a normal response to the stimulus (Fig. 4). Two in

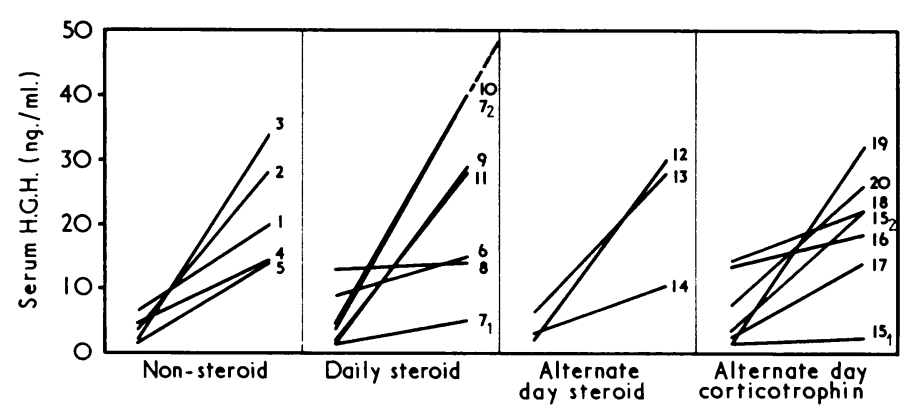

Fig. 3.-Serum growth hormone response to insulin hypoglycaemia. The lines join fasting level of growth hormone to maximum level attained during the test.

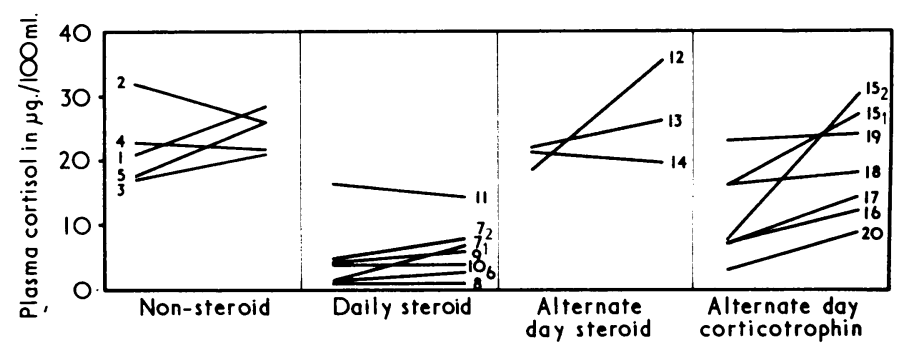

Fig. 4.-Plasma cortisol response to insulin hypoglycaemia. The lines join fasting level of plasma cortisol to maximum level attained during the test. 
TABLE II.-Cortisol and Growth Hormone Levels

\begin{tabular}{|c|c|c|c|c|c|c|c|c|}
\hline \multirow{3}{*}{ Case No. } & \multirow{3}{*}{$\begin{array}{c}\text { Mean Basal } \\
\text { G.H. } \\
\text { (ng./ml.) }\end{array}$} & \multirow{2}{*}{\multicolumn{2}{|c|}{$\frac{\text { Insulin Hypoglycaemia }}{\text { G.H. (ng./ml.) }}$}} & \multirow{3}{*}{$\begin{array}{c}\text { Mean Basal } \\
\text { Cortisol } \\
(\mu \mathrm{g} . / 100 \mathrm{ml} .)\end{array}$} & \multirow{2}{*}{\multicolumn{2}{|c|}{$\frac{\text { Insulin Hypoglycaemia }}{\text { Cortisol }(\mu \mathrm{g} . / 100 \mathrm{ml} .)}$}} & \multirow{2}{*}{\multicolumn{2}{|c|}{$\frac{\text { Insulin Hypoglycaemia }}{\text { Blood Sugar (mg./100 ml.) }}$}} \\
\hline & & & & & & & & \\
\hline & & Fasting & Maximum & & Fasting & Maximum & Fasting & Minimum \\
\hline
\end{tabular}

\begin{tabular}{|c|c|c|c|c|c|c|c|c|c|c|}
\hline \multicolumn{11}{|c|}{ Non-steroid Regimens, Group 1} \\
\hline & $\begin{array}{l}1 \\
2 \\
3 \\
4 \\
5\end{array}$ & $\begin{array}{l}\ldots \\
\ldots \\
\ldots \\
\ldots\end{array}$ & $\begin{array}{l}1.9 \\
2.8 \\
6.5 \\
1.7 \\
2.3\end{array}$ & $\begin{array}{l}6 \cdot 5 \\
3 \cdot 6 \\
2 \cdot 1 \\
4 \cdot 6 \\
1 \cdot 6\end{array}$ & $\begin{array}{l}20 \cdot 0 \\
28 \cdot 0 \\
34 \cdot 0 \\
14.5 \\
14 \cdot 0\end{array}$ & $\begin{array}{l}12 \cdot 7 \\
20 \cdot 7 \\
25 \cdot 0 \\
20 \cdot 5 \\
13.5\end{array}$ & $\begin{array}{l}21 \cdot 0 \\
32 \cdot 0 \\
17 \cdot 0 \\
22 \cdot 8 \\
17 \cdot 5\end{array}$ & $\begin{array}{l}28 \cdot 5 \\
26 \cdot 0 \\
21 \cdot 0 \\
22 \cdot 0 \\
26 \cdot 0\end{array}$ & $\begin{array}{l}64 \\
74 \\
70 \\
70 \\
74\end{array}$ & $\begin{array}{l}22 \\
58 \\
30 \\
30 \\
46\end{array}$ \\
\hline Mean & . & . & $3 \cdot 0$ & $3 \cdot 7$ & $22 \cdot 1$ & 18.5 & $22 \cdot 0$ & $24 \cdot 7$ & & \\
\hline
\end{tabular}

\begin{tabular}{|c|c|c|c|c|c|c|c|c|c|c|}
\hline \multicolumn{11}{|c|}{ Daily Corticosteroid, Group 2} \\
\hline & $\begin{array}{r}6 \\
7 \\
8 \\
9 \\
10 \\
11\end{array}$ & $\begin{array}{l}\cdots \\
\cdots \\
\cdots \\
\cdots \\
\cdots\end{array}$ & $\begin{array}{l}6.4 \\
1.5 \\
1.9 \\
1.6 \\
4.6 \\
6.0\end{array}$ & $\begin{array}{r}9.2 \\
1.5 \\
4.1 \\
13.0 \\
1.4 \\
4.6 \\
2.2\end{array}$ & $\begin{array}{r}15.0 \\
5.3 \\
>40.0 \\
14.0 \\
29.0 \\
>40.0 \\
28.0\end{array}$ & $\begin{array}{r}3 \cdot 0 \\
4.5 \\
3.0 \\
2.5 \\
4.0 \\
16.8\end{array}$ & $\begin{array}{r}1.5 \\
1.5 \\
5.0 \\
1.0 \\
4.5 \\
<4.0 \\
16.5\end{array}$ & $\begin{array}{r}3.0 \\
7.0 \\
8.0 \\
1.0 \\
6.0 \\
44.0 \\
14.5\end{array}$ & $\begin{array}{l}50 \\
72 \\
68 \\
72 \\
70 \\
70 \\
70\end{array}$ & $\begin{array}{l}26 \\
40 \\
28 \\
26 \\
26 \\
40 \\
30\end{array}$ \\
\hline Mean & . & $\ldots$ & $3 \cdot 7$ & $5 \cdot 1$ & $24 \cdot 7$ & $5 \cdot 6$ & $4 \cdot 8$ & $6 \cdot 2$ & & \\
\hline
\end{tabular}

\begin{tabular}{|c|c|c|c|c|c|c|c|c|c|c|}
\hline \multicolumn{11}{|c|}{ Alternate-day Corticosteroid, Group 3} \\
\hline & $\begin{array}{l}12 \\
13 \\
14\end{array}$ & $\begin{array}{l}\cdots \\
\cdots\end{array}$ & $\begin{array}{l}2.0 \\
2.5 \\
4.9\end{array}$ & $\begin{array}{l}1.9 \\
6.7 \\
2.9\end{array}$ & $\begin{array}{l}30 \cdot 0 \\
28 \cdot 0 \\
11.0\end{array}$ & $\begin{array}{l}14 \cdot 9 \\
17 \cdot 3 \\
15 \cdot 5\end{array}$ & $\begin{array}{l}18.5 \\
22 \cdot 0 \\
21.5\end{array}$ & $\begin{array}{l}35 \cdot 5 \\
26 \cdot 0 \\
19 \cdot 5\end{array}$ & $\begin{array}{l}70 \\
64 \\
72\end{array}$ & $\begin{array}{l}30 \\
38 \\
32\end{array}$ \\
\hline Mean & . & . & $3 \cdot 1$ & $3 \cdot 8$ & $23 \cdot 0$ & $15 \cdot 9$ & $20 \cdot 3$ & $27 \cdot 0$ & & \\
\hline
\end{tabular}

\begin{tabular}{|c|c|c|c|c|c|c|c|c|c|c|}
\hline \multicolumn{11}{|c|}{ Alternate-day Corticotrophin, Group 4} \\
\hline & $\begin{array}{l}15 \\
16 \\
17 \\
18 \\
19 \\
20\end{array}$ & $\begin{array}{l}\cdots \\
\cdots \\
\cdots \\
\cdots \\
\cdots\end{array}$ & $\begin{array}{l}1 \cdot 7 \\
2 \cdot 2 \\
4 \cdot 6 \\
2 \cdot 3 \\
1.6 \\
3 \cdot 9\end{array}$ & $\begin{array}{r}1.6 \\
3.4 \\
13.5 \\
2.4 \\
14.5 \\
1.6 \\
7.6\end{array}$ & $\begin{array}{r}2 \cdot 6 \\
22 \cdot 0 \\
18 \cdot 5 \\
14 \cdot 0 \\
22 \cdot 0 \\
32 \cdot 0 \\
26 \cdot 0\end{array}$ & $\begin{array}{r}10.5 \\
18.0 \\
2.8 \\
13.2 \\
10.0 \\
8.2\end{array}$ & $\begin{array}{r}16.0 \\
7.5 \\
7.0 \\
7.0 \\
16.0 \\
23.0 \\
<3.0\end{array}$ & $\begin{array}{r}27 \cdot 0 \\
30 \cdot 0 \\
12 \cdot 0 \\
14 \cdot 0 \\
18 \cdot 0 \\
24 \cdot 0 \\
8 \cdot 5\end{array}$ & $\begin{array}{l}50 \\
56 \\
78 \\
58 \\
60 \\
50 \\
52\end{array}$ & $\begin{array}{l}20 \\
22 \\
34 \\
20 \\
20 \\
20 \\
18\end{array}$ \\
\hline Mean & $\ldots$ & $\ldots$ & $2 \cdot 7$ & $6 \cdot 4$ & $19 \cdot 6$ & $10 \cdot 4$ & $11 \cdot 4$ & $19 \cdot 1$ & & \\
\hline
\end{tabular}

group 3 gave a normal response to the stimulus, while the third developed a maximum plasma cortisol just below $20 \mu \mathrm{g} . / 100 \mathrm{ml}$. Only two of the six in group 4 showed a normal response to hypoglycaemia; one had never previously been treated with corticosteroids while the other had received a combination of daily prednisone and intermittent corticotrophin for four and a half years before changing to corticotrophin therapy alone.

\section{Discussion}

In common with other chronic disease states, children with Still's disease show generalized growth retardation. This is independent of the local effects, which may result in premature epiphysial fusion and bizarre growth abnormalities, but is dependent on the duration and activity of the illness, only those with prolonged disease developing severe residual height defects (Ansell and Bywaters, 1956). Alteration in disease activity and therapy, local effects of disease, and discrepancies between chronological age and bone age make prognostication for final height difficult, but continuous long-term therapy with even moderate doses of corticosteroids results inevitably in further growth suppression. In the present series the two patients treated with alternate-day prednisone or corticotrophin from the outset showed no retardation of growth while those changed from daily prednisone to alternate-day corticotrophin developed at least partial recovery of growth. Patients changed from daily to alternate-day prednisone therapy were too few for clear assessment, but it is likely that control of disease activity by any means other than daily corticosteroid administration may allow some recovery of growth.

Basal levels of serum growth hormone were generally lower than those previously reported in children (Friedman and Stimmler, 1966; Morris et al., 1968a; Sanders and Norman, 1969) and similar to those reported in adults (Roth et al., 1963). It has been suggested that children and adults do not differ in basal secretion of growth hormone (Grumbach, 1966; Glick, 1967); and it may be that the precautions we have taken to avoid the effects of stimuli such as exercise and emotion, which can cause a marked increase in growth hormone secretion (Glick et al., 1965; Hunter et al., 1965; Greenwood and Landon, 1966), have contributed to the low basal levels. Though law basal levels of serum growth hormone have been interpreted as evidence of growth hormone deficiency (Frohman et al., 1967) we feel that the normal growth in at least some of our patients, together with the response to hypoglycaemia, indicates no significant impairment of growth hormone secretion.

Higher basal levels of serum growth hormone were found after cannulation for the insulin tolerance test, possibly owing to the stress of the procedure, and patients with particularly high resting levels showed a reduced response to hypoglycaemia. Similar findings have been recorded by other investigators (Frohman et al., 1967; Stimmler and Brown, 1967; Morris et al., 1968a) and were thought to have no pathological significance. Our findings of a normal growth hormone response to the test stimulus in patients on prolonged low-dosage corticosteroid therapy agree with the findings in two recent series of asthmatic children treated with long-term continuous steroids (Morris et al., 1968a; Sanders and Norman. 1969). The difference between these and previous studies (Frantz and Rabkin, 1964; Hartog et al., 1964) probably lies in the higher doses of steroids given to adults by the earlier investigators, though children also have shown some impairment of growth hormone release when given daily prednisone in doses of $7.5 \mathrm{mg}$. and above (Friedman and Greenwood, 1968). The results in our two patients who had repeat tests agree with the contention that a negative growth hormone response to a single adequate test stimulus does not permit a diagnosis of growth hormone deficiency (Raiti et al., 1967; Martin et al., 1968).

It is of interest that recent workers (Morris et al., 1968b) were unable to produce a stimulation of growth in their steroid-induced dwarfed children with doses of human growth hormone eight times those which will stimulate growth in children with hypopituitarism. Fortunately, the suppression of growth may be reversed by discontinuing the corticosteroids 
(Blodgett et al., 1956) or changing from a daily to an alternate-day regimen with either prednisone (Soyka, 1967) or corticotrophin (Friedman and Strang, 1966). Recovery does not always occur, and some patients appear to have a persistent retardation of growth (Norman and Sanders, 1969).

Fasting plasma cortisol levels before insulin hypoglycaemia were higher in some patients than their mean basal levels and probably represent a response to the stress of cannulation similar to that seen with growth hormone. Little further increase in plasma cortisol in response to hypoglycaemia in patients with already high basal levels has been reported (Bacon et al., 1968; Laron et al., 1969) and does not necessarily indicate a poor response to the test. Our patients treated without corticosteroids were within the normal range for basal cortisol secretion and response to hypoglycaemia, whereas those on daily corticosteroid therapy had low levels of plasma cortisol, except for one on a very low dose of prednisone, and none showed a normal response to hypoglycaemia.

Low basal levels of plasma cortisol in patients on corticosteroid therapy must be interpreted with caution as they may represent an effect of the previous day's steroid dose rather than chronic suppression of the hypothalamic-pituitaryadrenal axis. This could explain levels lower at 22 hours than at 46 hours in the patients on alternate-day prednisone, but those levels were within the normal range and indicate no significant impairment of basal cortisol secretion. Their response to hypoglycaemia was also normal. Other workers have reported variable impairment of circadian rhythm or response to hypoglycaemia in patients on alternate-day prednisone (Ackerman and Nolan, 1968; Jasani et al., 1968; Sadeghi-Nejad and Senior, 1969) and the dose of prednisone used is probably the critical factor in determining which patients will be affected.

The lower basal levels of plasma cortisol observed in the corticotrophin-treated patients 22 hours after injection of corticotrophin compared with those at 46 hours may at first seem anomalous, but the explanation probably also lies in the effect of the injection on the circadian rhythm of cortisol secretion. The declining levels of plasma cortisol in the evening after the injection will probably be sufficiently above the normal basal level to cause at least partial suppression of the following day's intrinsic rhythm, as has been described for physiological amounts of administered corticosteroid (Nichols et al. . 1965), with return to the normal circadian rhythm during the second 24 hours. Apart from one patient, however these patients also showed no significant impairment of basal cortisol secretion, though in those previously treated with long-term corticosteroids the response to hypoglycaemia was subnormal. It may be significant that a normal response to hypoglycaemia was seen in the patient who had never received corticosteroids and in the one who had previously received daily corticosteroid plus intermittent corticotrophin before changing to corticotrophin alone.

Lack of suppression of the hypothalamic-pituitary-adrenal axis by daily corticotrophin has been reported in adults
(Bacon et al., 1968; Carter and James, 1970) and children (Friedman and Greenwood, 1968), but this may not be invariable (Wynn, 1968). Alternate-day therapy with corticotrophin is presumably even less likely to cause suppression but it appears that full return of hypothalamic-pituitary-adrenal function after changing from long-term corticosteroid to alternate-day corticotrophin does not necessarily occur. We can offer no satisfactory explanation for this when compared with return of normal function in adults who had previously received corticosteroid therapy (Carter and James, 1970), but it is possible that differences in dose and duration of therapy account for the findings in our patients.

\section{REFERENCES}

Ackerman, G. L., and Nolan, C. M. (1968). New England fournal of Medicine, 278, 405

Ansell, B. M., and Bywaters, E. G. L. (1956). Annals of the Rheumatic Diseases, 15, 295

Bacon, P. A., Daly, J. R., Myles, A. B., and Savage, O. (1968). Annals of the Rheumatic Diseases, 27, 7

Beardwell, C. G., Burke, C. W., and Cope, C. L. (1968). Fournal of Endocrinology, 42, 79.

Blodgett, F. M., Burgin, L., Iezzoni, D., Gribetz, D., and Talbot, N. B. (1956). New England fournal of Medicine, 254, 636

Carter, M. E., and James, V. H. T. (1970). Annals of the Rheumatic Diseases, $29,73$.

Frantz, A. G., and Rabkin, M. T. (1964). New England fournal of Medicine, 271,1375

Friedman, M., and Greenwood, F. C. (1968). Memoirs of the Society for Endocrinology, 17, 249.

Friedman, M., and Stimmler, L. (1966). Lancet, 2, 944

Friedman, M., and Strang, L. B. (1966). Lancet, 2, 568

Frohman, L. A., Aceto, T., jun., and MacGillivray, M. H. (1967). Fournal of Clinical Endocrinology and Metabolism, 27, 1409.

Glick, S. M. (1967). Annals of Internal Mtdicine, 66, 760.

Glick, S. M., Roth, J., Yalow, R. S., and Berson, S. A. (1965). Recent Progress in Hormone Research, 21, 241.

Greenwood, F. C., and Landon, J. (1966). Nature, 210, 540.

Grumbach, M. M. (1966). Paediatrics, 37, 245.

Harter, J. G., Reddy, W. J., and Thorn, G. W. (1963). New England fournal of Medicine, 269, 591 .

Hartog, M., Gaafer, M. A., and Fraser, R. (1964). Lancet, 2, 376

Hunter, W. M., Fonseka, C. C., and Passmore, R. (1965). Science, 150, 1051 Jasani, M. K., et al. (1968). Annals of the Rheumatic Diseases, 27, 352.

Kaplan, S. A. (1969). In Endocrine and Genetic Diseases of Childhood, ed. L. I. Gardner, p. 98. Philadelphia, Saunders.

Laron, Z., Karp, M., Nitzan, M., and Pertzelan, A. (1969). Acta Endocrinologica (Kebenhavn), 60, 451

Martin, M. M., Gaboardi, F., Podolsky, S., Raiti, S., and Calcagno, P. L. (1968). New England fournal of Medicine, 279, 273.

Morris, H. G., Jorgenssen, J. R., Elrick, H., and Goldsmith, R. E. (1968a). Fournal of Clinical Investigation, 47, 427.

Morris, H. G., Jorgenssen, J. R., and Jenkins, S. A. (1968b). Fournal of Clinical Investigation, $47,436$.

Murphy, B. E. P. (1967). Fournal of Clinical Endocrinology and Metabolism, $27,973$.

Nichols, T., Nugent, C. A., and Tyler, F. H. (1965). fournal of Clinical Endocrinology and Metabolism, 25, 343 .

Norman, A. P., and Sanders, S. (1969). Lancet, 1, 287.

Raiti, S., Davis, W. T., and Blizzard, R. M. (1967). Lancet, 2, 1182.

Roth, J., Glick, S. M., Yalow, R. S., and Berson, S. A. (1963). Metabolism, 12, 577

Sadeghi-Nejad, A., and Senior, B. (1969). Pediatrics, 43, 277.

Sanders, S. S., and Norman, A. P. (1969). British Medical fournal, 3, 25

Soyka, L. F. (1967). American fournal of Diseases of Children, 113, 693.

Stimmler, L., and Brown, G. A. (1967). Archives of Diseases in Childhood, 42, 232 .

Talbot, N. B., and Sobel, E. H. (1947). Advances in Pediatrics, 2, 238.

Tanner, J. M., Whitehouse, R. H., and Takaishi, M. (1966). Archives of Diseases in Childhood, $41,613$.

Wynn, V. (1968). Memoirs of the Society for Endocrinology, 17, 213. 